\title{
EFFECT OF NITROGEN LEVELS ON GROWTH ATTRIBUTES, YIELD AND NUTRIENT UPTAKE OF DIFFERENT RICE (Oryza sativa L.) VARIETIES UNDER THE TRANSPLANTED CONDITION
}

\author{
Rakesh Maurya $^{1^{*}}$, Manoj Kumar Singh ${ }^{2}$, Nikhil Kumar Singh ${ }^{2}$, Manish Kumar Singh ${ }^{3}$, \\ Anurag Kumar Singh ${ }^{2}$
}

${ }^{1}$ SNRM, CPGSAS, CAU, Umiam, Meghalaya- 793 103, India
${ }^{2}$ Department of Agronomy I.Ag.Sc. BHU, Varanasi- 221005 India
${ }^{3}$ Department of Horticulture I.Ag.Sc. BHU,Varanasi- 221005 India

Received - December 21, 2020; Revision - July 13, 2021; Accepted - July 17, 2021

Available Online - October 20, 2021

DOI: http://dx.doi.org/10.18006/2021.9(Spl-3-NRMCSSA_2021).S336.S342

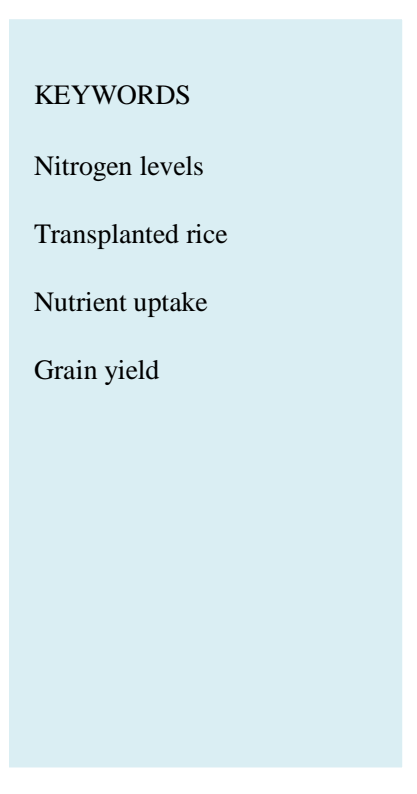

\begin{abstract}
Rice is very responsive to nitrogen fertilization under transplanted conditions; however $\mathrm{N}$ use efficiency and uptake by different varieties may vary. A field study was conducted during the rainy season of 2017 to assess the effect of four nitrogen levels in three rice varieties under the transplanted condition at Agricultural Research Farm, Banaras Hindu University, Varanasi, Uttar Pradesh. The experiment was carried out in a split-plot design (SPD) with three replications. The total number of treatments was twelve involving three rice varieties (V1- BPT-5204, V2- Rajendra Kasturi and V3- HUBR 2-1) in main plots and four nitrogen levels (N1- 100, N2- 120, N3- 140, and N4- $160 \mathrm{~kg} \mathrm{ha}^{-1}$ ) in sub-plots. Rice variety BPT- 5204 recorded significantly higher growth parameters viz. leaf number hill $^{-1}(37.17)$, SPAD value (chlorophyll content 31.83 ), the higher number of days taken to 50 percent flowering (103 days), maturity (130.17 days), grain yield (50.73 q ha $\left.{ }^{-1}\right)$, biological yield (112.90 q ha $\left.{ }^{-1}\right)$ and harvest index (0.45) as well as NPK uptakes by grain $\left(60.96,13.01 \& 10.95 \mathrm{~kg} \mathrm{ha}^{-1}\right)$ and straw $(29.72,7.15$ \& $\left.101.55 \mathrm{~kg} \mathrm{ha}^{-1}\right)$ as compared to other varieties. However, straw yield $\left(62.17 \mathrm{q} \mathrm{ha}^{-1}\right)$ was reported higher under HUBR 2-1 as compared to the rest varieties. Among the nitrogen levels, N4-160 kg $\mathrm{N} \mathrm{ha}^{-1}$ was recorded significantly higher above the same parameter as compared to other nitrogen levels. Hence, the application of $\mathrm{N} @ 160 \mathrm{~kg} \mathrm{ha}^{-1}$ along with rice variety BPT- 5204 can be recommended for achieving higher rice yield, nutrient uptake, and efficiency in Eastern Uttar Pradesh.
\end{abstract}

* Corresponding author

E-mail: rhmaurya1995@gmail.com (Rakesh Maurya)

Peer review under responsibility of Journal of Experimental Biology and Agricultural Sciences.

Production and Hosting by Horizon Publisher India [HPI] (http://www.horizonpublisherindia.in/).

All rights reserved.
All the articles published by Journal of Experimental Biology and Agricultural Sciences are licensed under a Creative Commons Attribution-NonCommercial 4.0 International License Based on a work at www.jebas.org.

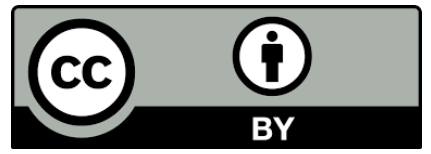




\section{Introduction}

Rice (Oryza sativa L.) is a staple food for more than half of the world's population, including two-thirds of the population of India (Sahu et al., 2015). After China, India is the world's second-largest rice producer. Rice is grown on 43.79 million hectares in India, with a yield of 116.42 million tonnes in 2018-2019 (Anonymous, 2019). Uttar Pradesh is the second largest rice growing state after West Bengal in the country, where it is grown over an area of about $5.75 \mathrm{~m}$ ha with the production of 15.54 million tons (Anonymous, 2019). The world's rice demand is projected to increase by $25 \%$ from 2001 to 2025 keeping pace with population growth and as a result, satisfying ever-increasing rice demand in a sustainable manner with depleting natural resources is a great challenge (Singh et al., 2016). In this endeavor, in addition to high-yielding rice varieties, efficient use of nutrients play an important role. Among the major plant nutrients, nitrogen is most important for augmenting rice yield.

Rice requires nitrogen in a higher amount than any other nutrient and so it has become a limiting factor that influences the grain yield of rice (Siddiqui et al., 2008). Application of optimum dose of nitrogen to rice is gaining importance because nitrogen is a key nutrient in crop production that it can never be ignored. It is crucial for the individual farmer as well as the country to get the maximum economic benefit out of the huge recurring expenditure. Under these circumstances, using suitable nitrogen management strategies to increase rice yield per unit area has become a vital component of current rice production technology (Fageria \& Baligar, 2001). The fertility and imbalanced fertilizer application coincide with maximum use of traditional varieties are the main constraints in rice production.

Identification and use of high yielding potential cultivars, though ensures higher yields, the actual yield advantage depends on the agronomic management including that of nitrogenous fertilizer management. The yield potential of a cultivar could be exploited to a maximum extent by judicious management of applied nitrogen as nitrogen deficiency is common in Indian soil. In general, 10-12 kg of rice is produced per $\mathrm{kg}$ of applied nitrogen but the degree of the response varies according to the season, soil qualities, variety, and cultural practices (Pillai et al., 1976). Rice varieties differ in their ability to uptake nitrogen from the soil as well as applied nitrogenous fertilizer and its distribution to different plant parts. Understanding nitrogen uptake and assimilation are critical in any strategy to maximize the efficiency of absorbed nitrogen for grain production. It is important to increase the efficiency of soil and applied nitrogen fertilizer by using nutrient-efficient varieties.

After the identification and release of high-yielding rice varieties, it became necessary to compare the results of growth studies and their impact on grain production under various nutrient combinations. Therefore, this study was carried out to evaluate the effect of nitrogen levels on growth attributes, yield, and nutrient uptake of different rice varieties under transplanted conditions.

\section{Materials and Methods}

The trial was conducted during the wet seasons of 2017 at Banaras Hindu University, Varanasi. The farm is on the Northern Gangetic Alluvial plains at $25^{\circ} 18^{\prime} \mathrm{N}$ latitude and $88^{\circ} 03^{\prime} \mathrm{E}$ longitude and an altitude of $128.93 \mathrm{~m}$ above the mean sea level. The meteorological data of weather parameters, viz. rainfall and temperature were recorded during the experiment. The highest amount of rainfall $139.8 \mathrm{~mm}$ by southwest monsoon was recorded in July and the maximum temperature was $40.1^{\circ} \mathrm{C}$ in June while the minimum temperature $16.8^{\circ} \mathrm{C}$ in November. Soil samples (0-15 cm depth) were collected from the experimental site before sowing and after harvesting, analyzed for mechanical and physicochemical properties. The soil texture was sandy clay loam (USDA), neutral in reaction $\mathrm{pH} 7.2$, low organic carbon $0.43 \%$ (Jackson, 1973), low in available nitrogen $202.7 \mathrm{~kg} \mathrm{ha}^{-1}$ (Subbiah \& Asija, 1956), medium in phosphorus pentoxide $\left(\mathrm{P}_{2} \mathrm{O}_{5}\right) 22.45 \mathrm{~kg} \mathrm{ha}^{-1}$ (Olsen et al., 1954), and potassium oxide $\left(\mathrm{K}_{2} \mathrm{O}\right) 209.2 \mathrm{~kg} \mathrm{ha}^{-1}$ (Jackson, 1973).

The experiment was laid out in a split-plot design with three rice varieties (V1- BPT-5204, V2- Rajendra Kasturi and V3- HUBR 21 with durations of 150,130 and 130 days respectively) in main plots and four nitrogen levels (N1- 100, N2- 120, N3- 140 and N4$160 \mathrm{~kg} \mathrm{ha}^{-1}$ ) in sub-plots with three replications and twelve treatment combinations. For the Varanasi region, the recommended dose of fertilizer (RDF) for $\mathrm{N}, \mathrm{P}_{2} \mathrm{O}_{5}$ and $\mathrm{K}_{2} \mathrm{O}$ (120$60-60 \mathrm{~kg} \mathrm{ha}^{-1}$ ) was used to compute various NPK levels. Half dose of nitrogen and a full dose of phosphorus, potassium were applied basal and the remaining half dose of nitrogen was applied in two equal splits at active tillering and panicle initiation stages as per treatments to their respective plots. Fertilizer sources used for NPK were urea $(46 \% \mathrm{~N})$, diammonium phosphate $(18 \% \mathrm{~N}$ and $46 \%$ $\left.\mathrm{P}_{2} \mathrm{O}_{5}\right)$, and muriate of potash $\left(60 \% \mathrm{~K}_{2} \mathrm{O}\right)$.

The nursery area was plowed once with disk plow followed by puddling and planking then desired seedbed was prepared. The twenty days seedling was transplanted at the spacing of $20 \mathrm{~cm}(\mathrm{R} \mathrm{x}$ $\mathrm{R})$ and $10 \mathrm{~cm}(\mathrm{P} \times \mathrm{P})$. Two seedlings at the depth of $2-3 \mathrm{~cm}$ were transplanted. Five $\mathrm{cm}$ water level was continuously maintained till flowering there after field was kept under saturated condition. Recommended agronomic practices were followed to raise the rice crop.

The data collected were chlorophyll content, number of leaves, number of days taken to $50 \%$ flowering and maturity, grain, straw, biological yield, and harvest index. The $\mathrm{N}$ content in grain and straw was analyzed by the micro Kjeldahl method. The Vanadomolybdo phosphoric acid yellow color method was used to 
determine phosphorus, while the flame photometer was used to determine potassium (Jackson, 1973). Individual treatment nutrien uptake was computed by multiplying the grain and straw yield with respective nutrient content. The ratio of grain yield to biological yield was calculated by using the following formula:

$$
\text { Harvest index }=\frac{\text { Economic yield } \times 100}{\text { Biological Yield }}
$$

While nutrient uptake in grain and straw of the crops were calculated in $\mathrm{kg} \mathrm{ha}^{-1}$ concerning yield $\mathrm{ha}^{-1}$ by the following formula:

Nutrient uptake $\left(\mathrm{kg} \mathrm{ha}^{-1}\right)=$ Nutrient content $(\%) \times \operatorname{yield}\left(\mathrm{q} \mathrm{ha}^{-1}\right)$

The data recorded were analyzed following standard statistical analysis of variance procedure as suggested by (Gomez \& Gomez, 1984).

\section{Results and Discussion}

3.1 Effect of nitrogen level and varieties on growth attributes and phenology

Results of the current study revealed that the number of leaves hill ${ }^{1}$ was significantly influenced by different varieties and nitrogen levels (Table 1). Variety BPT-5204 recorded a significantly higher number of leaves $\left(37.17 \mathrm{hill}^{-1}\right)$ at the level $\left(160 \mathrm{~kg} \mathrm{~N} \mathrm{ha}^{-1}\right)$ followed by HUBR 2-1 (34.50 hill $\left.^{-1}\right)$ and the lowest number of leaves hill was observed in the variety Rajendra Kasturi (32.92) at (100 kg N $\left.\mathrm{ha}^{-1}\right)$. An increase in the leaves number hill ${ }^{-1}$ means an increase the photosynthesis because the leaf is the factory for the conversion of light energy into chemical energy by the process of photosynthesis. These results are in agreement with the findings of Singh \& Kumar (2014).

Similarly, chlorophyll content (SPAD value) was also significantly influenced by the nitrogen level and the highest chlorophyll content was observed in the variety BPT-5204 (31.83) at level $160 \mathrm{~kg} \mathrm{~N} \mathrm{ha}^{-1}$ and the lowest SPAD value was observed in the variety Rajendra Kasturi (30.65) at $100 \mathrm{~kg} \mathrm{~N}^{-1}$ (Table 1). Chlorophyll content increased with an increase in nitrogen levels because nitrogen is an integral part of chlorophyll. An increase in the nitrogen rate increased the chlorophyll content of rice. A similar result was found by Bala subramaniyan \& Palaniappan (1991). Table 2 shows that plant population $\left(\mathrm{m}^{-2}\right)$ was not significantly influenced by different varieties and nitrogen levels.

Days taken to $50 \%$ flowering and maturity were significantly influenced by different rice varieties and nitrogen levels (Table 2). Among the varieties, BPT- 5204 significantly took a higher number of days taken to $50 \%$ flowering (103 days) and maturity (130.17 days) at the level $160 \mathrm{~kg} \mathrm{~N} \mathrm{ha}^{-1}$ as compared to HUBR 2-1 and the lowest number of days taken to $50 \%$ flowering (92.33 days) and maturity (119.17 days) was observed in Rajendra Kasturi variety at the level of $100 \mathrm{~kg} \mathrm{~N} \mathrm{ha}^{-1}$. However, nitrogen levels 140 and $120 \mathrm{~kg} \mathrm{~N} \mathrm{ha}^{-1}$ had statistically at par for the number of days taken for the maturity of rice.

Table 1 Effect of nitrogen levels on chlorophyll content (SPAD value) and number of leaves hill ${ }^{-1}$ of different rice varieties

\begin{tabular}{|c|c|c|c|c|c|c|}
\hline \multirow{2}{*}{ Treatment } & \multicolumn{2}{|c|}{ eulav DAPS } & \multicolumn{4}{|c|}{ Number of leaves hill ${ }^{-1}$} \\
\hline & $30 \mathrm{DAT}$ & 60 DAT & $30 \mathrm{DAT}$ & $60 \mathrm{DAT}$ & 90DAT & tsevrah $\mathrm{tA}$ \\
\hline \multicolumn{7}{|c|}{ yteiraV } \\
\hline ТPB5204 & 31.61 & 31.83 & 31.83 & 40.83 & 39.08 & 37.17 \\
\hline irutsaK ardnejaR & 28.48 & 30.65 & 27.58 & 37.42 & 34.83 & 32.92 \\
\hline RBUH2-1 & 29.78 & 31.33 & 28.83 & 39.08 & 36.92 & 34.50 \\
\hline SEm \pm & 0.08 & 0.12 & 0.74 & 0.48 & 0.35 & 0.25 \\
\hline $\mathrm{CD}(P=0.05)$ & 0.32 & 0.49 & 2.89 & 1.87 & 1.38 & 1.00 \\
\hline \multicolumn{7}{|c|}{ Nitrogen level $\left(\mathrm{kg} \mathrm{ha}^{-1}\right)$} \\
\hline 100 & 28.88 & 30.47 & 28.22 & 37.89 & 35.67 & 33.78 \\
\hline 120 & 29.50 & 30.84 & 29.11 & 38.78 & 36.44 & 34.44 \\
\hline 140 & 30.28 & 31.36 & 29.78 & 39.67 & 37.33 & 35.11 \\
\hline 160 & 31.17 & 32.41 & 30.56 & 40.11 & 38.33 & 36.11 \\
\hline SEm \pm & 0.20 & 0.11 & 0.54 & 0.53 & 0.49 & 0.48 \\
\hline $\mathrm{CD}(P=0.05)$ & 0.58 & 0.31 & 1.61 & 1.59 & 1.47 & 1.42 \\
\hline
\end{tabular}


Effect of nitrogen levels on growth attributes, yield and nutrient uptake of different rice varieties

Table 2 Effect of nitrogen levels on the number of days taken to $50 \%$ flowering, maturity, and plant population of different rice varieties

\begin{tabular}{|c|c|c|c|c|}
\hline \multirow{2}{*}{ Treatment } & \multirow{2}{*}{ Day to $50 \%$ flowering } & \multirow{2}{*}{ Day to maturity } & \multicolumn{2}{|c|}{ Plant population $\left(\mathrm{m}^{-2}\right)$} \\
\hline & & & Initial & Final \\
\hline \multicolumn{5}{|c|}{ yteiraV } \\
\hline ТРB5204 & 103.00 & 130.17 & 49.58 & 49.00 \\
\hline Rajendra Kasturi & 92.33 & 119.17 & 48.42 & 48.25 \\
\hline RBUH2-1 & 94.67 & 121.67 & 49.00 & 48.42 \\
\hline $\mathrm{SEm} \pm$ & 0.56 & 0.52 & 0.33 & 0.22 \\
\hline $\mathrm{CD}(P=0.05)$ & 2.18 & 2.03 & 1.31 & 0.86 \\
\hline \multicolumn{5}{|c|}{ Nitrogen level $\left(\mathrm{kg} \mathrm{ha}^{-1}\right)$} \\
\hline 100 & 94.67 & 121.78 & 48.67 & 48.33 \\
\hline 120 & 96.00 & 123.11 & 48.67 & 47.89 \\
\hline 140 & 97.33 & 124.22 & 49.44 & 49.33 \\
\hline 160 & 98.67 & 125.56 & 49.22 & 48.67 \\
\hline $\mathrm{SEm} \pm$ & 0.42 & 0.44 & 0.50 & 0.53 \\
\hline $\mathrm{CD}(P=0.05)$ & 1.26 & 1.32 & 1.47 & 1.58 \\
\hline
\end{tabular}

Table 3 Effect of nitrogen levels on grain yield, straw yield, biological yield and harvest index of different rice varieties

\begin{tabular}{|c|c|c|c|c|}
\hline Treatment & Grain yield ( $\mathrm{q} \mathrm{ha}^{-1}$ ) & Straw yield $\left(\mathrm{q} \mathrm{ha}^{-1}\right)$ & Biological yield $\left(\mathrm{q} \mathrm{ha}^{-1}\right)$ & Harvest index \\
\hline \multicolumn{5}{|c|}{ Variety } \\
\hline BPT -5204 & 50.73 & 62.17 & 112.90 & 0.45 \\
\hline Rajendra Kasturi & 32.67 & 72.08 & 104.75 & 0.31 \\
\hline HUBR 2-1 & 38.92 & 78.58 & 117.50 & 0.33 \\
\hline $\mathrm{SEm} \pm$ & 0.84 & 0.72 & 0.93 & 0.01 \\
\hline $\mathrm{CD}(P=0.05)$ & 3.31 & 2.84 & 3.64 & 0.02 \\
\hline \multicolumn{5}{|c|}{ Nitrogen level $\left(\mathrm{kg} \mathrm{ha}^{-1}\right)$} \\
\hline 100 & 37.03 & 67.22 & 104.26 & 0.35 \\
\hline 120 & 39.17 & 69.89 & 109.06 & 0.36 \\
\hline 140 & 42.22 & 72.22 & 114.44 & 0.37 \\
\hline 160 & 44.67 & 74.44 & 119.11 & 0.37 \\
\hline $\mathrm{SEm} \pm$ & 0.66 & 0.69 & 0.96 & 0.00 \\
\hline $\mathrm{CD}(P=0.05)$ & 1.98 & 2.04 & 2.85 & NS \\
\hline
\end{tabular}

\subsection{Effect of nitrogen level and varieties on yield}

The grain yield of rice is significantly influenced by different varieties and nitrogen levels (Table 3). The grain yield of BPT $5204\left(50.73 \mathrm{q} \mathrm{ha}^{-1}\right)$ at a level of $160 \mathrm{~kg} \mathrm{~N} \mathrm{ha}^{-1}$ was recorded significantly superior followed by HUBR 2-1(38.92 $\left.\mathrm{q} \mathrm{ha}^{-1}\right)$ with the same level of nitrogen and lowest grain yield was observed in
Rajendra Kasturi variety $\left(32.67 \mathrm{q} \mathrm{ha}^{-1}\right)$ at the level $100 \mathrm{~kg} \mathrm{~N} \mathrm{ha}^{-1}$. Nitrogen is one of the most important nutrients in increasing the yield component of rice which leads to increased yield. Mrudhula \& Suneetha (2020) reported that increased nitrogen levels up to $320 \mathrm{~kg} \mathrm{~N} \mathrm{ha}^{-1}$ significantly increased the grain yield of rice. However, the straw yield was significantly higher in HUBR 2-1 variety $\left(78.58 \mathrm{q} \mathrm{ha}^{-1}\right)$ at the level $160 \mathrm{~kg} \mathrm{~N} \mathrm{ha}^{-1}$ as compared to 
Rajendra Kasturi and the minimum straw yield was observed in BPT- $5204\left(62.17 \mathrm{q} \mathrm{ha}^{-1}\right)$ at the level $100 \mathrm{~kg} \mathrm{~N}^{-1}$. The biological yield was significantly influenced by different rice varieties and nitrogen levels. The highest biological yield (112.90 q ha $\left.{ }^{-1}\right)$ at level $160 \mathrm{~kg} \mathrm{~N} \mathrm{ha}^{-1}$ was recorded in variety BPT 5204 and the lowest was found in the Rajendra Kasturi (104.75 q ha $\left.{ }^{-1}\right)$ at level $100 \mathrm{~kg} \mathrm{~N}$ $\mathrm{ha}^{-1}$. Higher grain and straw yields might be attributed to a higher photosynthetic rate as a result of enhanced LAI, which in turn boosted dry matter formation, resulting in higher grain and straw yields. The findings of the previous study were supported by these findings by Davari \& Sharma (2010) and Murthy et al. (2012) who reported that increasing levels of nitrogen progressively enhanced yield attributes, grain, and straw yield of rice. Harvest index was significantly influenced by different rice varieties but did not significantly influence due to nitrogen levels. The harvest index was highest recorded in variety BPT- $5204(0.45)$ followed by HUBR 2-1 (0.33) and lowest was found in the Rajendra Kasturi (0.31) at the dose $100 \mathrm{~kg} \mathrm{~N}^{-1}$ however, harvest index was statistically at par HUBR 2-1 and Rajendra Kasturi variety. Hossain et al. (2008) reported that the difference of variety had a great influence on the harvest index.

\subsection{Effect of nitrogen level and varieties on $N, P, K$ content and uptake in grain and straw}

Nitrogen content in grain and straw was significantly influenced by different varieties and nitrogen levels (Table 4). At a level of 160 $\mathrm{kg} \mathrm{N} \mathrm{ha}{ }^{-1}$, the variety BPT-5204 produced significantly higher nitrogen content in grain (1.20) and straw (0.48) as compared to
HUBR 2-1 and the lowest nitrogen content was observed in Rajendra Kasturi in grain (1.10) and straw (0.39) at level $100 \mathrm{~kg} \mathrm{~N}$ $\mathrm{ha}^{-1}$. Among the nitrogen level significantly highest nitrogen content was found with $160 \mathrm{~kg} \mathrm{~N} \mathrm{ha}^{-1}$ and the lowest was found with $100 \mathrm{~kg} \mathrm{~N} \mathrm{ha}^{-1}$ in both grain and straw. Variation in nitrogen content in grain was at par with the level of 120 to $100 \mathrm{~kg} \mathrm{~N} \mathrm{ha}^{-1}$. About $73 \%$ of nitrogen translocated to grain in non-aromatic rice varieties, with the rest remaining in the straw, whereas only $47 \%$ of nitrogen translocated to grain in aromatic varieties (De et al., 2002). However, $P$ and $K$ content was not significantly influenced by different varieties and nitrogen levels in both grain and straw.

The amount of $\mathrm{N}, \mathrm{P}$ and $\mathrm{K}$ uptake by grain and straw was significantly influenced by different varieties and nitrogen levels (Table 5). Among the varieties, BPT- 5204 at a level of $160 \mathrm{~kg} \mathrm{~N}$ $\mathrm{ha}^{-1}$ recorded significantly higher NPK uptake in grain and the lowest nitrogen uptake was observed in Rajendra Kasturi at level $100 \mathrm{~kg} \mathrm{~N} \mathrm{ha}^{-1}$. Among the varieties, $\mathrm{K}$ uptake in grain was statistically at par with HUBR 2-1 and Rajendra Kasturi variety. Among the nitrogen level, $160 \mathrm{~kg} \mathrm{~N} \mathrm{ha}^{-1}$ have significantly higher $\mathrm{N}\left(52.23 \mathrm{~kg} \mathrm{ha}^{-1}\right)$ and $\mathrm{P}\left(11.17 \mathrm{~kg} \mathrm{ha}^{-1}\right)$ uptakes in grain and lowest $\mathrm{N}, \mathrm{P}$ uptakes were observed at level $100 \mathrm{~kg} \mathrm{~N}^{-1}$ (40.34) and (8.33) $\mathrm{kg} \mathrm{ha}^{-1}$ respectively, while $\mathrm{K}$ uptake in grain was not significantly influenced due to nitrogen level. $\mathrm{N}$ uptake in straw was significantly higher in HUBR 2-1 variety and lowest observed in Rajendra Kasturi. While N uptake in straw by HUBR 2-1 and BPT- 5204 variety statistically at par the higher uptake of $\mathrm{N}$ with $160 \mathrm{~kg} \mathrm{~N} \mathrm{ha}^{-1}$ might be due to application of more amount of $\mathrm{N}$ in more number of splits leading to increased uptake. Similarly,

Table 4 Effect of nitrogen levels on N, P and K content (\%) in grain and straw of different rice varieties

\begin{tabular}{|c|c|c|c|c|c|c|}
\hline \multirow{2}{*}{ Treatment } & \multicolumn{2}{|c|}{$\mathrm{N}$ content $(\%)$} & \multicolumn{2}{|c|}{$\mathrm{P}$ content $(\%)$} & \multicolumn{2}{|c|}{ K content $(\%)$} \\
\hline & Grain & Straw & Grain & Grain & Straw & Grain \\
\hline \multicolumn{7}{|c|}{ yteiraV } \\
\hline ТРB- 5204 & 1.20 & 0.48 & 0.22 & 1.63 & 0.22 & 1.63 \\
\hline irutsaK ardnejaR & 1.05 & 0.36 & 0.20 & 1.56 & 0.20 & 1.56 \\
\hline RBUH2-1 & 1.10 & 0.39 & 0.21 & 1.59 & 0.21 & 1.59 \\
\hline $\mathrm{SEm} \pm$ & 0.01 & 0.01 & 0.01 & 0.01 & 0.01 & 0.01 \\
\hline $\mathrm{CD}(P=0.05)$ & 0.03 & 0.02 & NS & NS & NS & NS \\
\hline \multicolumn{7}{|c|}{ Nitrogen level $\left(\mathrm{kg} \mathrm{ha}^{-1}\right)$} \\
\hline 100 & 1.08 & 0.37 & 0.22 & 0.08 & 0.21 & 1.57 \\
\hline 120 & 1.10 & 0.39 & 0.23 & 0.09 & 0.21 & 1.58 \\
\hline 140 & 1.13 & 0.43 & 0.24 & 0.10 & 0.21 & 1.60 \\
\hline 160 & 1.16 & 0.45 & 0.25 & 0.10 & 0.20 & 1.62 \\
\hline SEm \pm & 0.01 & 0.01 & 0.00 & 0.00 & 0.01 & 0.01 \\
\hline $\mathrm{CD}(P=0.05)$ & 0.02 & 0.02 & NS & NS & NS & NS \\
\hline
\end{tabular}

Journal of Experimental Biology and Agricultural Sciences http://www.jebas.org 
Table 5 Effect of nitrogen levels on $\mathrm{N}, \mathrm{P}$ and $\mathrm{K}$ uptake $\left(\mathrm{kg} \mathrm{ha}^{-1}\right)$ in grain and straw of different rice varieties

\begin{tabular}{|c|c|c|c|c|c|c|}
\hline \multirow{2}{*}{ Treatment } & \multicolumn{2}{|c|}{$\mathrm{N}$ uptake $\left(\mathrm{kg} \mathrm{ha}^{-1}\right)$} & \multicolumn{2}{|c|}{ P uptake $\left(\mathrm{kg} \mathrm{ha}^{-1}\right)$} & \multicolumn{2}{|c|}{ K uptake $\left(\mathrm{kg} \mathrm{ha}^{-1}\right)$} \\
\hline & Grain & Straw & Grain & Straw & Grain & Straw \\
\hline \multicolumn{7}{|c|}{ yteiraV } \\
\hline TPB- 5204 & 60.96 & 29.72 & 13.01 & 7.15 & 10.95 & 101.55 \\
\hline irutsaK ardnejaR & 34.41 & 26.26 & 7.03 & 5.16 & 6.35 & 112.52 \\
\hline RBUH2-1 & 42.88 & 30.94 & 8.94 & 6.78 & 8.06 & 124.90 \\
\hline SEm \pm & 0.95 & 0.56 & 0.29 & 0.11 & 0.50 & 1.51 \\
\hline $\mathrm{CD}(P=0.05)$ & 3.72 & 2.19 & 1.12 & 0.42 & 1.96 & 5.92 \\
\hline \multicolumn{7}{|c|}{ Nitrogen level $\left(\mathrm{kg} \mathrm{ha}^{-1}\right)$} \\
\hline 100 & 40.34 & 24.81 & 8.33 & 4.96 & 7.63 & 105.45 \\
\hline 120 & 43.53 & 27.35 & 9.01 & 5.93 & 8.15 & 110.59 \\
\hline 140 & 48.23 & 30.49 & 10.13 & 6.87 & 8.90 & 115.49 \\
\hline 160 & 52.23 & 33.25 & 11.17 & 7.70 & 9.14 & 120.41 \\
\hline SEm \pm & 0.80 & 0.59 & 0.16 & 0.13 & 0.32 & 1.28 \\
\hline $\mathrm{CD}(P=0.05)$ & 2.39 & 1.74 & 0.48 & 0.38 & NS & 3.79 \\
\hline
\end{tabular}

statistically significant $\mathrm{N}$ uptake was reported with the increasing levels of N (Marlar et al., 2007). Furthermore, among varieties, BPT- $5204\left(7.15 \mathrm{~kg} \mathrm{ha}^{-1}\right)$ was recorded a significantly higher uptake of $\mathrm{P}$ in straw, and the lowest was observed in Rajendra Kasturi $\left(6.78 \mathrm{~kg} \mathrm{ha}^{-1}\right)$. The uptake of $\mathrm{K}$ was significantly higher in HUBR 2-1 as compared to other varieties. On the other hand, the uptake of $\mathrm{N}, \mathrm{P}$ and $\mathrm{K}$ in straw was significantly higher at the application of $160 \mathrm{~kg} \mathrm{~N} h a^{-1}$ and $100 \mathrm{~kg} \mathrm{~N} \mathrm{ha}^{-1}$, the lowest uptake was recorded. The higher N, P and $\mathrm{K}$ uptake may be due to more available nutrients, and better translocation of the nutrients in prolong submergence situations resulted in higher yield recorded in these treatments (Sathish et al., 2011; Ramalakshmi et al., 2012).

\section{Conclusion}

Considering the results obtained from the study it can be concluded that BPT-5204 variety was superior over the rest of the varieties and among nitrogen levels the best level was $160 \mathrm{~kg} \mathrm{~N} \mathrm{ha}^{-1}$.

\section{Conflict of interest}

The authors would hereby like to declare that there is no conflict of interests that could arise.

\section{References}

Anonymous (2019) Directorate of Economics and Statistics. Ministry of Agriculture and Farmers Welfare Department of Agriculture, Cooperation \& Farmers Welfare, Government of India. Agricultural statistical at a glance data2019. Available at
https://eands.dacnet.nic.in/PDF/At\%20a\%20Glance\%202019\%20

Eng.pdf access on $29^{\text {th }}$ April, 2020.

Balasubramaniyan P, Palaniappan S (1991) Effect of high density population and fertilizer rate on growth and yield of low land rice. Indian Journal of Agronomy 36: 10-13.

Davari MR, Sharma SN (2010) Effect of different combinations of organic materials and bio-fertilizers on Productivity grain quality and economics in organic farming of basmati rice. Indian Journal of Agronomy 55: 290-294.

De DK, Pal SK, Ghosh M, Pal AK, Basak S (2002) Evaluation of aromatic rice cultivars in foot hill zones of West Bengal. Indian Journal of Agricultural Sciences 72: 379-382.

Fageria NK, Baligar VC (2001) Lowland rice response to nitrogen fertilization. Communications in Soil Science and Plant Analysis 30: 1405-1429.

Gomez KA, Gomez AA (1984) Statistical Procedure of Agricultural Research. John Wiley and Sons, New York, USA. Pp. 200-215.

Hossain MB, Islam MO, Hasanuzzaman M (2008) Influence of different nitrogen levels on the performance of four aromatic rice varieties. International Journal Agricultural Biology 10:693-699.

Jackson ML (1973) Soil Chemical Analysis, Prentice Hall of India Pvt. Ltd. New Delhi Pp. 183-204. 
Marlar NO, Shivay YS, Kumar D (2007) Effect of nitrogen and sulphur fertilization on yield attributes, Productivity and nutrient uptake of aromatic rice. Indian Journal of Agricultural Sciences 77: 772- 775 .

Mrudhula KN, Suneetha Y (2020) Effect of nitrogen levels on growth, yield attributes and yield of rice variety BPT 2231Akshaya. Pharma Innovation Journal 9: 218-221.

Murthy KVR, Reddy DS, Reddy GP (2012) Response of rice varieties to graded levels of nitrogen under aerobic culture. Indian Journal of Agronomy 57: 367-372.

Olsen SR, Cole CV, Walanabe FS, Dean LA (1954) Estimation of available phosphorus in soil by extraction with sodium bicarbonate. United States Department of Agriculture Circular 939: 19-23.

Pillai KG, Rao AV, Sarma YRB, Rao NS (1976). Economics of nitrogen fertilization for dwarf rice varieties. Fertilizer News 21: 34-36.

Ramalakshmi CS, Rao PC, Sreelatha T, Mahadevi M, Padmaja G, Rao PV, Sireesha A (2012) Nitrogen use efficiency and production efficiency of rice under rice-pulse cropping system with integrated nutrient management. Journal of Rice Research 5: 42-51.
Sahu YK, Chaubey AK, Mishra VN, Rajput AS, Bajpai RK (2015) Effect of integrated nutrient management on growth and yield of rice in inceptisol. Plant Archives 15: 983-986.

Sathish A, Govinda GV, Chandrappa H, Nagaraja K (2011) Long term effect of integrated use of organic and inorganic fertilizers on productivity, soil fertility and uptake of nutrient in rice and maize cropping system. International Journal Science and Nature 2: 84-88.

Siddiqui MH, Khan MN, Mohammad F, Khan MMA (2008) Role of nitrogen and gibberellin in the regulation of enzyme activities and in osmoprotectant accumulation in under salt stress. Journal of Agronomy and Crop Science 194:214-224.

Singh VP, Singh SP, Dhyani VC, Banga A, Kumar A, Satyawali $\mathrm{K}$, Bisht N (2016) Weed management in direct-Seeded rice. Indian Journal of Weed Science 48: 233-246.

Singh, D, Kumar A (2014) Effect of sources of nitrogen growth yield and uptake of nutrients in rice. Annals of Plant and Soil Research 16: 359- 361.

Subbiah BV, Asija GL (1956) A rapid procedure for estimation of available nitrogen in soils. Current Sciences 25: 259-260. 